\title{
党支部建设 “三原色”一一高校学生党支部工作方式创新研究
}

\author{
揭镭 \\ 南昌航空大学 \\ DOI:10.32629/er.v3i9.3150
}

\begin{abstract}
[摘 要] 高校学生党支部是党在大学生中的基层组织,是高校党建的重要组成部分。做好高校学生党支 部的建设,有利于提高学生党员的责任意识和充分发挥学生党支部的战斗堡垒作用,有利于切实提高高 校党建工作的质量。本文对高校学生党支部工作方式提出了新方法, 通过高校学生党支部 “三原色” 工 程,抓好支部的基础建设,提升支部活力,为构建建 “学习型、创新型、服务型” 党支部打下坚实基础。
\end{abstract} [关键词] 高校; 党支部; 工作方式 中图分类号: D26 文献标识码: A

高校学生党支部是党在大学生中 的基层组织, 作为高校党建的重要组成 部分, 是大学生与党组织在思想上进行 沟通的坚实桥梁, 2017年教育部《普通 高等学校学生党建工作标准》明确指 出: “建强学生党支部, 充实支部工作力 量, 创新支部工作方法, 保障支部工作 条件。”做好学生党支部建设和大学生 党员的教育和管理, 有利于提高学生党 员的责任意识和充分发挥学生党支部 的战斗堡垒作用, 有利于切实提高高校 党建工作的质量。

\section{1 当前高校学生党支部工作方 式现状}

长期以来, 高校学生党支部存在支 部活动单一、支部活动开放性互动性不 强, 党支部理论教育与实践教育融合不 足等情况, 进而造成大学生党员出现消 极解急, 对支部组织生活不重视, 学生党 员的先锋模范带头作用得不到体现, 阻 碍了学生党员先进性的发挥。

\section{2 创新高校学生党支部工作} 方式

在色彩中, 三原色指色彩中不能再 分解的三种基本颜色, 我们通常说的三 原色, 即红、黄、青 (是青不是蓝, 蓝是品 红和青混合的颜色)。三原色可以混合出 所有的颜色, 对于色彩来说, 三原色就是 所有颜色基础。高校学生党支部也可以 通过 “三原色” 工程, 即红色、黄色、青

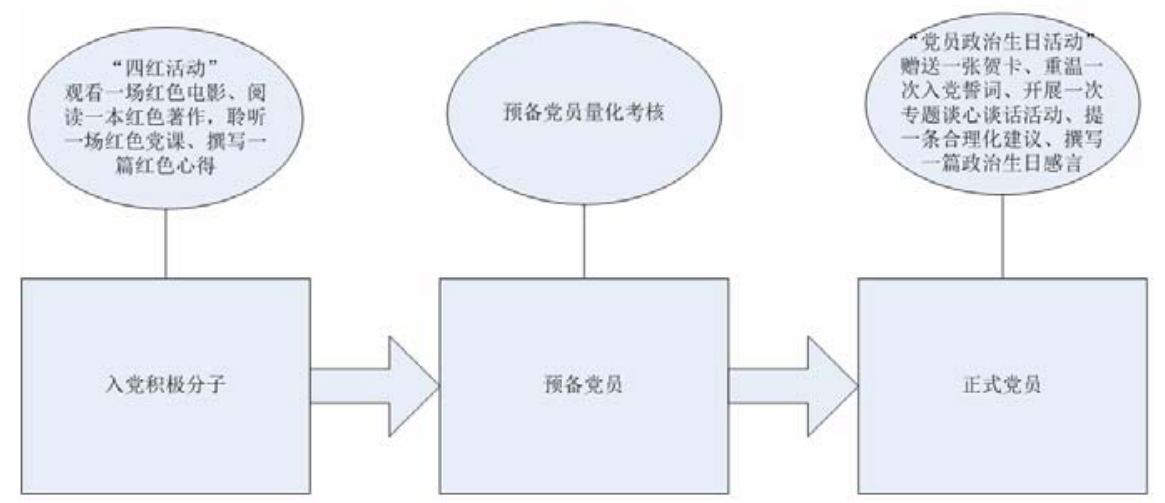

色三色工程来作为支部工作的基础, 改 进支部工作方式, 创新支部工作方法, 提 高支部工作创造力, 吸引学生支部党员 积极主动参与支部活动, 提升支部活力, 发挥学生党员先锋模范作用。

\section{1 红色工程}

红色是革命的颜色, 是理想信仰的 颜色。中国共产党成立 90 多年来, 为了人 民当家作主浴血奋战, 带领中华民族历 经从东亚病夫到东方巨龙、从百年沉沦 到百年复兴的历史命运。信仰坚定是我 们党在领导革命和建设事业中战无不胜 的精神武器, 信仰是政党的灵魂, 信仰是 精神旗帜, 也是每名党员思想和行动的 总开关。有信仰的人, 会为自己的信仰调 动自身的一切力量, 集中到既定的目标 上, 其知识、能力、内心世界都会得到充 实和提高, 从而推动个人及社会的发展。 高校大学生党员普遍存在党的理论认识
不够, 进而容易产生信仰不坚定的情况, 高校学生党支部建设应当始终把学生党 员的思想建设、信仰建设作为党的建设 的制高点, 放在首位, 从入党积极分子阶 段开始, 通过开展 “四红” 活动, 激请支 部入党积极分子观看一场红色电影、阅 读一本红色著作, 聆听一场红色党课、撰 写一篇红色心得四项活动, 帮助入党积 极分子树立正确的入党动机, 坚定其理 想信仰, 帮助他们树立为人民服务的思 想。在入党以后, 特别是转为正式党员以 后, 学生党员容易存在消极解急情况, 在 支部建立学生党员监督考核制度, 通过 指标体系和量化考核, 将考核结果纳入 到学生党员评先评优体系中, 并及时将 考核依据和结果公示, 把学生党员量化 考核作为强化党员教育、规范党员行为、 提升党员素质、发挥党员先锋作用的有 效手段。在支部中还可以开展党员 “政 
治生日” 活动, 通过赠送一张贺卡、重温 一次入党誓词、开展一次专题谈心谈话 活动、提一条合理化建议、撰写一篇政 治生日感言的 “五个一” 模式, 切实增强 党员光荣感和责任感, 切实改进党员教 育、管理与服务工作, 发挥党员先锋模范 作用, 将人性化教育方式融入到“两学一 做” 学习教育中。通过以上举措, 让高校 学生党支部成为学生党员不断坚定理想 信仰、保持纯洁性的坚强堡垒。

\section{2 黄色工程}

黄色是温暖的颜色, 高校学生党支部 要在 “服务型” 党支部上下大力气, 把党 员志愿服务活动作为党支部的一项重要 工作, 把它作为学生党员与普通同学, 学 生支部与相应的班级紧密联系的一座重 要桥梁, 通过学生党员的志愿服务活动, 温暖普通同学的心灵。在学习方面, 针对 学习困难的同学, 支部建立学生党员与学 习困难同学 “ $1+1$ ” 帮扶档案, 针对学习困 难同学弱项专门进行帮扶, 每学年检验帮 扶成果, 在每年的迎新, 校园环境整治, 寝 室卫生保持等等方面支部党员都要走在 前列, 充分发挥学生党员志愿服务的作用, 关心帮助普通同学, 在广大学生中树立起 学生党员的先进形象。有条件的支部还应 组织学生党员赴偏远中小学、养老院、残 疾人机构等弱势群体开展志愿服务活动。 在今年的疫情防控和抗洪救灾活动中, 学 生党支部应积极鼓励学生党员参与到当 地的疫情防控和抗洪救灾活动中去, 并做 好思想引领工作, 帮助学生党员进一步树 立为人民服务的思想, 密切学生党员和普 通群众的联系, 使支部战斗堡垒的作用得 到充分发挥。

\section{3 青色工程}

青色代表创新, 高校学生党支部建

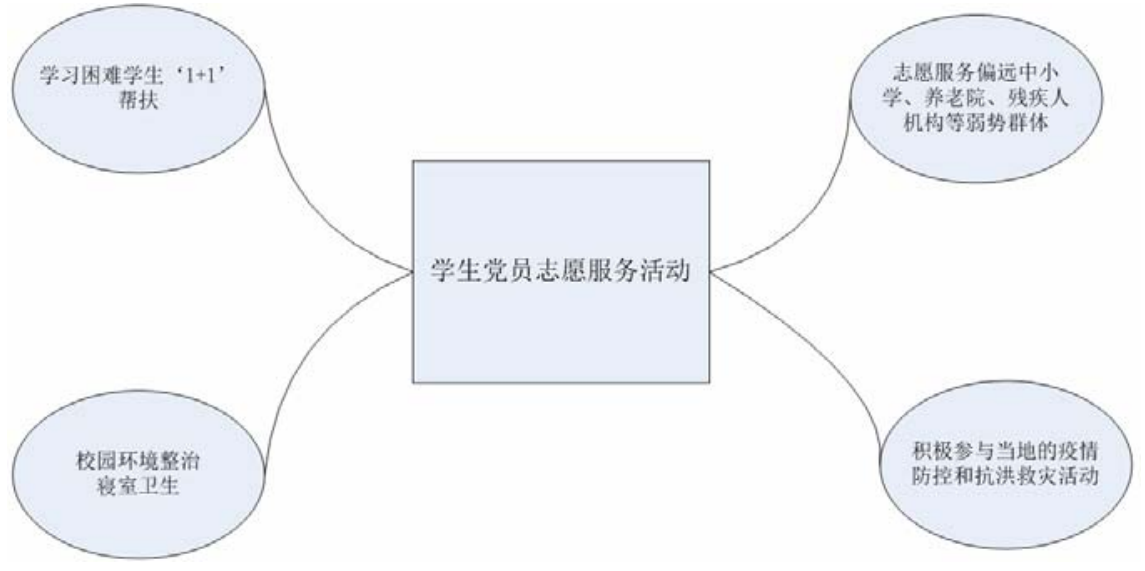

设不能一成不变, 特别是在支部组织生 活方面, 在支部中开展 “青色工程”, 就 是要通过创新支部组织生活方式, 运用 网络新媒体, 通过网络视频, 参观红色教 育基地等方式, 丰富支部组织生活内容。 通过学院学生党总支集合所有支部开展 学习实践活动, 让学院内支部学生党员 有互相充分交流的机会, 在当前许多学 生支部和教工支部都在同一系部上建立, 可以打破组织生活的壁垒, 让同一系部 的教工党支部和学生党支部一起开展支 部活动, 运用支部教师党员的力量, 在学 业引导、比赛竞赛、日常生活等方面帮 助支部学生党员; 利用微信、微博等网 络新媒体平台, 将支部近期工作计划, 支 部活动开展情况及时更新到微信公众号 或者微博平台上, 让更多的普通同学和 入党积极分子了解所在想学生支部情 况。在2020年新冠疫情期间, 通过网络视 频会议, 讲好疫情防控的爱国主义故事。 通过支部 “青色工程”, 创新高校学生党 支部工作方法, 进一步提升高校学生党 支部活力。

高校党委通过在学生党支部中开展 “三原色”工程, 进一步抓好高校学生党
支部的基础建设, 学生党支部也可以通 过 “三原色” 工程, 创新支部工作方法, 加强对学生党员的教育和管理, 培养出 爱党爱社会主义、有坚定的共产主义信 仰信念、对党忠诚的接班人。

\section{[基金项目]}

2018年江西省高校党建研究项目 (项目编号：18DJQN020)。

\section{[参考文献]}

[1]中共中央组织部、中共教育部党 组、共青团中央.关于加强和改进在大学 生中发展党员工作和大学生党支部建设 的意见[M].北京: 人民出版社,2005.

[2]郭丰.高校学生党支部建设路径 初探[J].长江丛刊,2016,(21):236.

[3]付颖.高校学生党支部建设探析[J]. 开封教育学院学报,2015,35(07):204-205.

[4] 展.高校学生党支部建设创新探 析[J].新西部(理论版),2015,(16):126+120.

\section{作者简介：}

揭鐇(1985--), 男, 汉族, 江西南丰人, 南昌航空大学国有资产管理处党支部副 书记,思政讲师,主要从事国有资产管理 与党建方面的工作。 